Łukasz Kazmierski ${ }^{1}$, Szymon Roszkowski²,

${ }^{1}$ Department of Tissue Engineering, Collegium Medicum, Nicolaus Copernicus University, Poland

${ }^{2}$ Fculty of Agronomy and Bioengineering, Poznan University of Life Sciences, Poland

\title{
Plant stem cells culture - a new tool for skin protection and regeneration
}

\author{
Corresponding author: \\ Szymon Roszkowski, Student \\ Faculty of Agronomy \\ and Bioengineerring, \\ Poznan University of Life Sciences; \\ tel. +4852 3743472; \\ e-mail: roszkowski.sz11@gmail.com
}

Medical Research Journal 2019;

Volume 4, Number 1, 52-57

DOI: 10.5603/MRJ.a2018.0030

Copyright (C) 2019 Via Medica

ISSN 2451-2591

\begin{abstract}
Development of biotechnology, esthetic medicine and cosmetology can enable us to slow down or delay the skin aging process. Currently, much attention is aimed at treatments using substances of plant origin. They have been proven to exhibit antioxidant, antibacterial and antifungal properties, accelerate wound healing, moisturize the skin, enhance skin renewal processes and protect skin against UV radiation. Biologically active plant-derived compounds, however, are often produced by plants in very small amounts. A solution to this problem is an in vitro culture of callus tissue, representing plant stem cells. Both, in vitro and in vivo studies demonstrated beneficial effects of plants stem cell extracts on human skin in the battle against ageing. The aim of this paper was to provide a review of studies based on the use of plant stem cells in limiting skin ageing.
\end{abstract}

Key words: phytotherapy; plant-derived compounds; plant stem cells; skin ageing

Med Res J 2019; 4 (1): 52-57

\section{Introduction}

The skin is the largest organ of the human body and performs many physiological functions, including protection against the adverse effects of external factors, body temperature regulation, secretion and absorption of various agents [1-3]. The skin consists of a number of specialized cells forming three layers: epidermis, dermis and subcutaneous tissue. Each layer plays a different, but very important role in maintaining the proper functions of the entire body [1]. Homeostasis of the skin (all of its layers) is possible by the presence of various stem cell populations located mainly in the epidermis (interfollicular compartments, the bulge region of the follicle, sebaceous glands). Their presence and condition determine regeneration and skin cell renewal while maintaining a balance between all layers [4]. It also allows for maintaining a healthy-looking skin, which is an attribute of each person. Unfortunately, over time skin undergoes an inevitable ageing process which is irreversible and affects every human being. Skin ageing is a result of overlapping multiple mechanical, biological, biochemical and molecular processes, which begins around age 25-30. Depending on the causes, ageing can be both intrinsic and/or extrinsic [5-7]. The first one is determined genetically and hormonally and is highly time-dependent. The second one, called also photoaging, is caused by various external factors affecting the skin (eg. UV radiation, cigarette usage, pollution and stress [5-8].

However, thanks to advances in many areas of biotechnology and medicine, it is possible to slow down or significantly delay this complex process. Properly selected nutrients as well as cosmetic care are crucial in the renewal and regeneration of skin and increasing its resistance to external factors such as sudden changes in temperature, strong wind, pollution and UV radiation. Currently, a great amount of attention is paid towards treatments that may delay skin ageing and/or eliminate visible symptoms of this process. Among cosmetics based on natural raw materials (such as creams and lotions), cosmetological treatments (including facials and infusions), as well as various skin injections, surgery and laser treatments, are used. Treatments with various kinds of cosmetics (creams, facials) that contain a number of biologically active substances having anti-ageing, anti-wrinkle, bleaching properties, etc., are commonly applied due to their ease of use and low risk of complications or adverse side effects. For years, those types of cosmetics, great importance was assigned to regenerative properties of plants. They contain ingredients that are necessary to carry out all metabolic processes responsible for the renewal of the epidermis, increasing the skin elasticity, scavenging free radicals and maintaining an adequate level of hydration. 
The aim of this review was to provide an overview of the studies concerning the use of plant stem cells in the case of limiting the skin ageing.

\section{Plant compounds in cosmetics}

Plants are a natural resource, used for centuries for cosmetic and therapeutic purposes. There are many cosmetics, of which the active compounds are the main base. These compounds are obtained by extraction with various kinds of solvents from selected plants. They affect preferably the condition of the skin and prevent the loss of elasticity by stimulating synthesis of collagen and elastin fibres. They also exhibit antioxidant, antibacterial and antifungal properties, accelerate wound healing, moisturize the skin, enhance skin renewal processes and protect skin against the harmful effects of UV radiation [9]. There are a number of substances of plant origin which positive effects on the skin were confirmed. These are vitamins, unsaturated fatty acids, saponins, phytohormones, flavonoids, alkaloids and carotenoids.

\section{Vitamins}

Vitamins serve as antioxidants, support the renewal of damaged collagen and elastin fibres. Vitamin C serves one of the most important roles, it is a potent antioxidant that protects skin from free radicals created inter alia by UV radiation - photoprotection [10, 11]. Vit. C plays also a key role in the synthesis of collagen $[11,12]$ since its presence is necessary for the proper functioning of proline hydroxylase and lysine hydroxylase. These enzymes are responsible for the formation of the correct collagen molecule, the main protein responsible for maintaining the skin mechanical properties [12-14]. There have also been reports demonstrating the specific role of tocopherol (vitamin E) in scarring and wound healing processes [15]. This compound is also involved in the stabilization of biological membranes and, is also a strong antioxidant. Its deficiency, in turn, can severely accelerate the aging processes [14]. Fruits and vegetables are a rich source of vitamins [10], ones with a high overall vitamin content are primarily: rosehips [16, 17], blackcurrant [18, 19], chokeberry [19], tomatoes, kiwi [20], avocado [21], strawberries, papaya and broccoli [11].

\section{Unsaturated fatty acids}

Unsaturated fatty acids are one of the components of the most external layer of the epidermis (Stratum corneum), and it's built of corneocytes [22, 23]. They increase the flexibility of cell membranes, help to maintain an adequate level of hydration and skin tightening, enhance the epidermal barrier function and support defensive processes of the skin. A deficiency of these components in the skin, may cause severe skin diseases such as eczema [24]. It also leads to the reduction in hydration, which in turn results in reduced flexibility and accelerated the formation of wrinkles [21, 25]. Due to the presence of multiple bonds unsaturated fatty acids exhibit antioxidant activity, reducing the risk of formation of free radicals that accelerate the ageing process and can lead to skin cancers. Unsaturated fatty acids are achieved mainly from vegetable oils contained, inter alia, in black cumin seed [26], avocado [27], primrose [28] or hemp oil [25].

\section{Saponins}

Saponins are a group of compounds belonging to the glycoside. They exhibit properties similar to soap since they have the ability to decrease the surface tension and cause the foaming process [29]. These make them useful in cosmetic products designed for skin cleaning and toning such as tonics, make-up removers or cleaning gels. Another, very important, the feature of saponins is the ability to penetrating through the lipid layer of the skin due to the presence of a lipophilic aglycone in their structure. This property facilitates the absorption of other active substances contained in cosmetics by increasing membrane permeability [30]. Scientific studies have shown that saponins applied to the skin exposure to UV radiation, inhibit the appearance of wrinkles and increasing the thickness of the skin and loss of their elasticity. This made them highly effective photoprotective compounds [30]. Saponins are mainly found in the leaves of plants such as ginseng [30], acacia [31], soybeans and spinach [29].

\section{Phytohormones}

Phytohormones serve an excellent alternative to the human hormones (such as estrogen) which are used in many types of beauty products. Scientific studies have shown the positive effects of estrogen skin on regeneration. It also decreases the aging process [32, 33]. However, the use of such compounds has been banned because they caused too many side effects, unlike their plant counterparts [34]. Plant hormones prevent cell membranes damage and its oxidation. Phytohormones exhibit inhibitory activity of collagenase, elastase and hyaluronidase - enzymes that cause water loss and reduce the skin elasticity, making it more susceptible to the aging processes [35]. In in vivo studies, a cream containing phytohormones caused a reduction in wrinkle depth after a few weeks of use [36]. In addition, it has been shown that phytohormones can reduce the deposition of fat so can be successfully used in cosmetics that modelling the face oval. Common sources of these compounds are grapefruit, ginseng, dates, soybeans or wheat [35]. 


\section{Flavonoids}

Flavonoids are applied in skin care products mostly due to its powerful antioxidant properties, which can be up to 100 and 25-times stronger than vitamin $\mathrm{C}$ and vitamin E, respectively [35]. Furthermore, they accelerate wound healing, inflammatory and antibacterial processes. Provide also an excellent barrier to UV rays. That is why they can be used to reduce the natural skin ageing process and protect it from the damaging effects of free radicals [37]. In an indirect way, flavonoids affect the condition of the blood vessels in the skin by stabilizing the unoxidized form of vitamin $\mathrm{C}$, which is responsible for maintaining their cohesiveness. It was also shown that flavonoids inhibit elastase and hyaluronidase activity [35]. Flavonoids derived mainly from citrus fruits, tomatoes, vegetables, legumes, broccoli, blueberries, bilberries and grapes.

\section{Alkaloids}

Alkaloids which are metabolites of many plants are now also used in cosmetic preparations. The best-known and most frequently used are caffeine, quindoline, allocryptopine. Caffeine extracted from seeds of Coffea arabica is the most common, due to the ability to penetrating the skin very effectively [38]. It is also reported that caffeine has the ability to reduce the risk of skin cancer, after exposure to UV radiation [39]. Furthermore, caffeine is also often used in firming, anti-cellulite and slimming cosmetics due to its lipolytic properties [40].

\section{Carotenoids}

The use of carotenoids in cosmetics is less popular than the above-mentioned compounds, but their protective properties for the skin are also very important. The greatest source of lycopene and $\beta$-carotene - the main representatives of carotenoids - are commonly available in red vegetables, such as tomatoes, peppers and carrots. Carotenoids have an antioxidant property and are therefore widely used in cosmetics which are applied against the UV radiation. It also has shown a high antitumor property for various types of cancers [21].

\section{Obtaining plant derived-compounds}

Plant-derived biologically active compounds used in cosmetology and aesthetic dermatology are mainly secondary metabolites. Their receiving from natural plant sources is often a complex, time-consuming and usually inefficient process. This is mainly due to the fact that secondary metabolites are produced in plants in an amount less than $1 \%$ of dry weight [41]. Therefore, obtaining of appropriate quantities of desirable compounds requires their isolation from a large amount of plant material. This factor is extremely limited due to the presence of geographical barriers; variability of the seasons, which is bound with the growth of the majority of plant species, as well as various culture conditions that may hinder the obtaining plant material. The problem is also protected species of plants which use, even for scientific studies, require the appropriate permits [9, 41]. On the other hand, obtaining of plant compounds by chemical synthesis is often impossible, because they have usually very complex structure (polycyclic, containing a plurality of chiral centers) [41].

A solution of the above problems came with the intensive development of biotechnology and in vitro culture of plants [9, 42]. They allow a culture of selected organs or plant cells in solid, controlled conditions, reducing the time necessary to obtain a large amount of material, in relation to the whole plant breeding. In recent years, particular interest is focused on in vitro cultures of callus tissue, as a plant stem cells. Callus is a plant tissue resulting from the undifferentiation of adult plant cells at the site of mechanical injury. To initiate this type of the culture even a small explant of the plant can be used. This allows obtaining a large amount of material (biologically active substances) in the relatively short time, without breeding of the whole plant. Therefore, the stem cells of plants are an alternative to obtaining the biologically active compounds from selected plants.

\section{Plant stem cells}

Plant stem cells (PSCs) are the source of a number of factors supporting the skin protection and regeneration processes and thereby inhibit skin ageing. The first reports about the possibility of using stem cells derived from plants in cosmetic products have appeared in 2008 [43]. Extracts from stem cells such plants as apple (Malus domestica) varieties Uttwiler Spätlaubersą, argan (Argania spinosa), alpenrose (Rhododendron ferrugineum), grape vine (Vitis vinifera), samphire (Crithmum maritimum) and tomato (Lycopersicon esculentum), have been analyzed so far. Both, in vitro and in vivo studies demonstrated beneficial effects of stem cell extracts of above standard plant extracts on the skin. However, PSCs derived from different plants have varying biological properties.

Stem cells derived from apple fruit and argan stimulate the proliferation and survival of human stem cells $[43,44]$ and in the case of apple PSCs - protect them from the adverse effects of UV radiation [43]. These results suggest that stem cells derived from plants 
Table 1 Clinical trials of plant stem cells extracts on skin regeneration

\begin{tabular}{|c|c|c|c|}
\hline Stem cells source & Participants & Application & Results \\
\hline $\begin{array}{l}\text { Apple } \\
\text { (Malus domestica) } \\
\text { - clinical trial } \\
\text { (Schmid et al. 2008; } \\
\text { Schmid 2009) }\end{array}$ & $\begin{array}{l}20 \text { women } \\
\text { age: } \\
37-64 \text { years }\end{array}$ & $\begin{array}{l}\text { cream with } 2 \% \text { cell extract; two } \\
\text { times a day for } 4 \text { weeks }\end{array}$ & $\begin{array}{l}\text { - significant reduction of wrinkles by } 8 \% \text { and } \\
15 \% \text { after } 2 \text { and } 4 \text { weeks respectively. }\end{array}$ \\
\hline $\begin{array}{l}\text { Argan } \\
\text { (Argania spinosa) } \\
\text { - clinical trial } \\
\text { (Montaño 2012) }\end{array}$ & $\begin{array}{l}21 \text { women } \\
\text { age: } \\
39-61 \text { years }\end{array}$ & $\begin{array}{l}\text { emulsion with } \\
0,4 \% \text { cell extract; two times a day } \\
\text { for } 56 \text { days }\end{array}$ & $\begin{array}{l}\text { - reduction of wrinkles by } 19 \% \text { and } 27 \% \text { after } \\
28 \text { and } 56 \text { days respectively. } \\
\text { — increase in skin density of } 12.7 \% \text { after } 8 \\
\text { weeks }\end{array}$ \\
\hline $\begin{array}{l}\text { Samphire } \\
\text { (Crithmum maritimum) } \\
\text { - comparative intra- } \\
\text {-individual, controlled, } \\
\text { randomized pilot study } \\
\text { (Caucanas et al. 2011) }\end{array}$ & $\begin{array}{l}12 \text { volunteers } \\
\text { age: older than } \\
50 \text { years }\end{array}$ & $\begin{array}{l}\text { - cream with } 0.05 \% \text { cell extract, } \\
\text { - cosmetic serum with } 0,1 \% \text { cell } \\
\text { extract, } \\
\text { - silicone oil with } 0,5 \% \text { cell extract } \\
\text { once a day for } 2 \text { weeks, } \\
\text { observations for another } 2 \text { weeks }\end{array}$ & $\begin{array}{l}\text { - improvement of skin permeability barrier } \\
\text { function by: significant decreases in } \\
\text { transepidermal water loss (TEWL), between } \\
\text { day } 16 \text { and } 29 \text {; smoothing of the skin } \\
\text { between day } 15 \text { and } 29 \text {; significant skin } \\
\text { moisturization at day } 29 \text { compared to day } 1 \\
\text { _ no adverse events were observed }\end{array}$ \\
\hline
\end{tabular}

can contribute to both, protection and regeneration of the skin. Additionally, PSCs extract from apple fruit also showed antioxidant properties by stimulating the expression of genes which play an important role in the regulation, cell growth and proliferation (cyclin B1 and E1, p53, IGF II, heme oxygenase 1) [43]. Samphire stem cells extract have a positive influence on the proliferation and viability of human keratinocytes and fibroblasts [45]. Tomato stem cells, in turn, exhibit a protective effect on murine keratinocytes and fibroblasts cells during oxidative stress induced by certain heavy metals (Ni and $\mathrm{Pb}$ ). It stimulated the production of collagen I and III by fibroblasts in the presence of heavy metals and decreased the expression of collagenases: MMP 1, 3 and 9, which rises in the above conditions [46]. In in vivo studies using human skin model (SE, skin equivalent model) suggest the increase of cell proliferation in the presence of PSCs, samphire extract. This resulted in the growing thickness of the individual skin layers and increased cell density in both the epidermis and dermis [45]. In clinical studies, extract of stem cells from samphire improved epidermal permeability barrier repair and revealed the soothing and moisturizing effect on the skin [47]. The extracts of apple and argan stem cells, in turn, reduced wrinkles appearing around the eyes ("crow's feet") and resulted in an increase of skin density $[43,48,49]$. Detailed information about clinical trials of plant stem cells applications are presented in Table 1.

\section{Conclusion}

The continued desire of society to maintain a healthy, youthful appearance forced to search for novel ways to inhibit and even reverse the ageing processes. There are many rejuvenating treatments that restoring the skin's youthful appearance, ranging from simple creams application and plastic surgery in the ending. Although the invasive methods give the most spectacular effects, in a relatively short period of time, they are often painful and carry a risk of side effects (scars or wounds difficult to heal). Therefore, researchers are currently focused on the search for natural methods to fight with the signs of unavoidable skin ageing. One of such methods is the use of plant-derived compounds in cosmetic and dermo-cosmetics.

The plants are a very rich source of many biologically active compounds, which are used in many areas of our lives. Studies confirm the beneficial effects of many substances of plant origin on the functioning and protection of the skin. Their use in cosmetics and personal care products protect the skin against the damaging effects of external factors, promotes skin regeneration processes and inhibit and/or slow down the ageing process. This allows maintaining a healthy, firm skin for many years. The use of plant compounds provides many advantages. As these are natural compounds, they rarely lead to undesirable side effects. Furthermore, they are not complex in use and available to all, because of the form of its administration - mostly creams, masks and lotions.

Currently, in addition to the standard compounds of plant origin, much attention is also paid to the plants stem cells. They appear to be a promising material for use in cosmetology and aesthetic dermatology due to its protective and regenerative properties. Studies, conducted so far, confirmed the potential of these cells in the fight against the signs of skin ageing, emphasizing their beneficial effects on stem cells, which is crucial to the process of skin renewal.

\section{Disclosure of interest: The authors declare no conflict of interest}




\section{References}

1. Arda $O$, Göksügür $N$, Tüzün $Y$. Basic histological structure and functions of facial skin. Clin Dermatol. 2014; 32(1): 3-13, doi: 10.1016/j. clindermatol.2013.05.021, indexed in Pubmed: 24314373.

2. Bordoni B, Zanier E. Skin, fascias, and scars: symptoms and systemic connections. J Multidiscip Healthc. 2013; 7: 11-24 doi: 10.2147/JMDH.S52870, indexed in Pubmed: 24403836.

3. Kendall AC, Nicolaou A. Bioactive lipid mediators in skin inflammation and immunity. Prog Lipid Res. 2013; 52(1): 141-164 doi: 10.1016/j.plipres.2012.10.003, indexed in Pubmed: 23124022

4. Uzarska M, Porowińska D, Bajek A, et al. [Epidermal stem cells--biology and potential applications in regenerative medicine]. Postepy Biochem. 2013; 59(2): 219-227, indexed in Pubmed: 24044286.

5. Puizina-Ivić N. Skin aging. Acta Dermatovenerol Alp Pannonica Adriat. 2008; 17(2): 47-54, indexed in Pubmed: 18709289

6. Kohl E, Steinbauer J, Landthaler M, et al. Skin ageing. J Eur Acad Dermatol Venereol. 2011; 25(8): 873-884, doi: 10.1111/j.1468 -3083.2010.03963.x, indexed in Pubmed: 21261751

7. Zegarska B, Woźniak M. Reasons of endogenous aging of the skin. Gerontologia Polska. 2006; 14: 153-159.

8. Sveikata K, Balciuniene I, Tutkuviene J. Factors influencing face aging. Literature review. Stomatologija. 2011; 13(4): 113-116 indexed in Pubmed: 22362337.

9. Schürch C, Blum P, Zülli F. Potential of plant cells in culture for cosmetic application. Phytochemistry Reviews. 2007; 7(3): 599-605, doi: 10.1007/s11101-007-9082-0.

10. Guz J, Dziaman T, Szpila A. [Do antioxidant vitamins influence carcinogenesis?]. Postepy Hig Med Dosw (Online). 2007; 61: 185-198, indexed in Pubmed: 17507866.

11. Telang PS. Vitamin C in dermatology. Indian Dermatol Online J. 2013; 4(2): 143-146, doi: 10.4103/2229-5178.110593, indexed in Pubmed: 23741676

12. Qiao H, Bell J, Juliao S, et al. Ascorbic acid uptake and regulation of type I collagen synthesis in cultured vascular smooth muscle cells. J Vasc Res. 2009; 46(1): 15-24, doi: 10.1159/000135661. indexed in Pubmed: 18515971.

13. Baumann L. Skin aging and its treatment. J Pathol. 2007; 211 241-251.

14. Sroka Z, Gamian A, Cisowski W. [Low-molecular antioxidant compounds of natural origin]. Postepy Hig Med Dosw (Online). 2005; 59: 34-41, indexed in Pubmed: 15761384

15. Rahmani N, Hashemi SA, Ehteshami S. Vitamin E and its clinical challenges in cosmetic and reconstructive medicine with focus on scars; a review. J Pak Med Assoc. 2013; 63(3): 380-382 doi: 10.1093/occmed/kqt059, indexed in Pubmed: 23914643.

16. Roman I, Stănilă A, Stănilă S. Bioactive compounds and antioxidant activity of Rosa canina L. biotypes from spontaneous flora of Transylvania. Chem Cent J. 2013; 7(1): 73, doi: 10.1186/1752153X-7-73, indexed in Pubmed: 23618509

17. Demir F, Özcan M. Chemical and technological properties of rose (Rosa canina L.) fruits grown wild in Turkey. Journal of Food Engineering. 2001; 47(4): 333-336, doi: 10.1016/s02608774(00)00129-1.

18. Hancock R, Walker P, Pont S, et al. L-Ascorbic acid accumulation in fruit of Ribes nigrum occurs by in situ biosynthesis via the L-galactose pathway. Functional Plant Biology. 2007; 34(12): 1080 doi: 10.1071/fp07221

19. Graversen H, Becker E, Skibsted L, et al. Antioxidant synergism between fruit juice and -tocopherol. A comparison between high phenolic black chokeberry (Aronia melanocarpa) and high ascorbic blackcurrant (Ribes nigrum). European Food Research and Technology. 2007; 226(4): 737-743, doi: 10.1007/s00217007-0585-0.

20. Collins AR, Harrington V, Drew J, et al. Nutritional modulation of DNA repair in a human intervention study. Carcinogenesis. 2003 24(3): 511-515, doi: 10.1093/carcin/24.3.511, indexed in Pubmed: 12663512

21. Dreher ML, Davenport AJ. Hass avocado composition and potential health effects. Crit Rev Food Sci Nutr. 2013; 53(7): 738-750, do i: 10.1080/10408398.2011.556759, indexed in Pubmed: 23638933.

22. Bouwstra JA, Dubbelaar FE, Gooris GS, et al. The lipid organisation in the skin barrier. Acta Derm Venereol Suppl (Stockh). 2000 208: 23-30, indexed in Pubmed: 10884936.

23. van Smeden J, Janssens M, Gooris GS, et al. The important role of stratum corneum lipids for the cutaneous barrier function. Biochim Biophys Acta. 2014; 1841(3): 295-313, doi: 10.1016/j. bbalip.2013.11.006, indexed in Pubmed: 24252189
24. Horrobin DF. Essential fatty acid metabolism and its modification in atopic eczema. Am J Clin Nutr. 2000; 71(1 Suppl): 367S-72S, doi: 10.1093/ajcn/71.1.367s, indexed in Pubmed: 10617999.

25. Schagen SK, Zampeli VA, Makrantonaki E, et al. Discovering the link between nutrition and skin aging. Dermatoendocrinol. 2012; 4(3): 298-307, doi: 10.4161/derm.22876, indexed in Pubmed: 23467449

26. Mańkowska D, Bylka W. Nigella Sativa L. - Active compounds, biological properties. Herba polonica. 2009; 55: 109-125

27. Takenaga F, Matsuyama K, Abe S, et al. Lipid and fatty acid composition of mesocarp and seed of avocado fruits harvested at northern range in Japan. J Oleo Sci. 2008; 57(11): 591-597, doi: 10.5650/jos.57.591, indexed in Pubmed: 18838831.

28. Simon D, Eng PA, Borelli S, et al. Gamma-linolenic acid levels correlate with clinical efficacy of evening primrose oil in patients with atopic dermatitis. Adv Ther. 2014; 31(2): 180-188, doi: 10.1007/s12325-014-0093-0, indexed in Pubmed: 24435467.

29. Güçlü-Ustündağ O, Mazza G. Saponins: properties, applications and processing. Crit Rev Food Sci Nutr. 2007; 47(3): 231-258, doi: 10.1080/10408390600698197, indexed in Pubmed: 17453922.

30. Kim YG, Sumiyoshi M, Sakanaka M, et al. Effects of ginseng saponins isolated from red ginseng on ultraviolet B-induced skin aging in hairless mice. Eur J Pharmacol. 2009; 602: 148-156, doi: 10.1016/j.ejphar.2008.11.021.

31. Hanausek M, Ganesh P, Walaszek Z, et al. Avicins, a family of triterpenoid saponins from Acacia victoriae (Bentham), suppress $\mathrm{H}$-ras mutations and aneuploidy in a murine skin carcinogenesis model. Proc Natl Acad Sci U S A. 2001; 98(20): 11551-11556, doi: 10.1073/pnas.191363198, indexed in Pubmed: 11572997.

32. Verdier-Sévrain S. Effect of estrogens on skin aging and the potential role of selective estrogen receptor modulators. Climacteric. 2007; 10(4): 289-297, doi: 10.1080/13697130701467157, indexed in Pubmed: 17653955

33. Stevenson S, Thornton J. Effect of estrogens on skin aging and the potential role of SERMs. Clin Interv Aging. 2007; 2(3): 283-297, doi: 10.2147/cia.s798, indexed in Pubmed: 18044179.

34. De Orsi D, Pellegrini M, Pichini S, et al. High-performance liquid chromatography-diode array and electrospray-mass spectrometry analysis of non-allowed substances in cosmetic products for preventing hair loss and other hormone-dependent skin diseases. J Pharm Biomed Anal. 2008; 48(3): 641-648, doi: 10.1016/j. jpa.2008.06.008, indexed in Pubmed: 18656319.

35. Bakoyiannis I, Daskalopoulou A, Pergialiotis V, et al. Phytochemicals and cognitive health: Are flavonoids doing the trick? Biomed Pharmacother. 2019; 109: 1488-1497, doi: 10.1016/j. biopha.2018.10.086, indexed in Pubmed: 30551400.

36. Reuter J, Wölfle U, Korting HC, et al. Which plant for which skin disease? Part 2: Dermatophytes, chronic venous insufficiency, photoprotection, actinic keratoses, vitiligo, hair loss, cosmetic indications. J Dtsch Dermatol Ges. 2010; 8(11): 866-873, doi: 10.1111/j.1610-0387.2010.07472.x, indexed in Pubmed: 20707877.

37. Singh RP, Agarwal R. Cosmeceuticals and silibinin. Clin Dermatol. 2009; 27(5): 479-484, doi: 10.1016/j.clindermatol.2009.05.012, indexed in Pubmed: 19695480

38. Trauer S, Patzelt A, Otberg N, et al. Permeation of topically applied caffeine through human skin--a comparison of in vivo and in vitro data. Br J Clin Pharmacol. 2009; 68(2): 181-186, doi: 10.1111/j.1365-2125.2009.03463.x, indexed in Pubmed: 19694736.

39. Lu YP, Lou YR, Peng QY, et al. Caffeine decreases phospho-Chk1 (Ser317) and increases mitotic cells with cyclin B1 and caspase 3 in tumors from UVB-treated mice. Cancer Prev Res (Phila). 2011; 4(7): 1118-1125, doi: 10.1158/1940-6207.CAPR-11-0116, indexed in Pubmed: 21505179

40. Mori S, Satou M, Kanazawa S, et al. Body fat mass reduction and up-regulation of uncoupling protein by novel lipolysis-promoting plant extract. Int J Biol Sci. 2009; 5(4): 311-318, doi: 10.7150/ijbs.5.311, indexed in Pubmed: 19421341.

41. Kubala A. Biological methods of obtaining medical compounds in botany. Gazeta Farmaceutyczna 2013; 26-28. http://polona pl/item. ; 36820267.

42. Anand S. Various approaches for secondary metabolite production through plant tissue culture. Pharmacia. 2010; 1: 1-7.

43. Schmid D, Schürch C, Blum P, et al. Plant Stem Cell Extract for Longevity of Skin and Hair. Int J Applied Sci. 2008; 134: 29-35.

44. Schmid D, Belser E, Zuelli F. Vitalisation of dermal stem cells for skin rejuvenation. Personal Care. ; 2011: 33-35. 
45. Lequeux $\mathrm{C}$, Lhoste $\mathrm{A}$, Rovere MR, et al. Model of in vitro healing to tes the influence of dedifferentiated Crithmum maritimum cells on dermal repair and epidermal regeneration. Skin Pharmacol Physiol. 2011 24(2): 75-80, doi: 10.1159/000321991, indexed in Pubmed: 21088454

46. Tito A, Carola A, Bimonte M, et al. A tomato stem cell extract, containing antioxidant compounds and metal chelating factors, protects skin cells from heavy metal-induced damages. Int J Cosmet Sci. 2011 33(6): 543-552, doi: 10.1111/j.1468-2494.2011.00668.x, indexed in Pubmed: 21609336.
47. Caucanas M, Montastier C, Piérard GE, et al. Dynamics of skin barrier repair following preconditioning by a biotechnology-driven extract from samphire (Crithmum maritimum) stem cells. J Cosmet Dermatol. 2011 10(4): 288-293, doi: 10.1111/j.1473-2165.2011.00584.x, indexed in Pubmed: 22151937

48. Schmid D. Stimuli for skin stem cells for real skin rejuvenation. Household and Personal Care. 2009; 1: 26-28.

49. Montaño I. Dermal stem cells are the target of the latest treatments for deep-seated skin regeneration. Mibelle Biochemistry, Switzerland; 2012: 1-6. 